\title{
Assessment of Anwai river water quality using the weighted arithmetic water quality index (WQI) in Delta State, Nigeria
}

\author{
Kate Isioma Iloba* \\ Department of Animal and Environmental Biology, Delta State University, Abraka, Delta State, \\ Nigeria \\ Nelson Owese Akawo \\ Department of Biology Education, Federal College of Education (Technical), Asaba, Delta \\ State, Nigeria \\ Perry Irouoghene Godwin \\ Department of Animal and Environmental Biology, Delta State University, Abraka, Delta State, \\ Nigeria \\ *Corresponding author. Email: kisyiloba@gmail.com
}

\section{Article Info}

https://doi.org/10.31018/ jans.v13i3.2758

Received: June 12, 2021

Revised: August 3, 2021

Accepted: August 8, 2021

\section{How to Cite}

Iloba, K. I. et al. (2021). Assessment of Anwai river water quality using the weighted arithmetic water quality index (WQI) in Delta State, Nigeria. Journal of Applied and Natural Science, 13(3), 913 - 922. https://doi.org/10.31018/jans.v13i3.2758

\begin{abstract}
The weighted arithmetic water quality index method was used to assess the water quality of anthropogenically-laden Anwairiver within the Asaba-capital territory of Delta State, Nigeria, in Stations 1(Otulu), 2(Isele- asagba) and 3(Anwai-Asaba) using $\mathrm{pH}$, electrical conductivity (EC), total dissolved solids (TDS), biochemical oxygen demand (BOD), dissolved oxygen (DO), turbidity, phosphates, nitrates, total hardness $(\mathrm{TH})$ and coliforms, to determine its water quality status and its suitability for humans and aquatic biota. Aside from TDS, turbidity, and TH, other parameters such as $\mathrm{pH}$ (5.3-8.2), DO (2.0-2.8 mg/L), BOD (1.02-2.4 $\mathrm{mg} / \mathrm{L})$, EC (110-113 $\mu \mathrm{S} / \mathrm{cm})$, turbidity(2.3-5.2 NTU), TDS (8.0-16.0 mg/L), TH (30-62 mg/L), phosphates $(0.13-0.28 \mathrm{mg} / \mathrm{L})$, nitrates $(0.05-0.27 \mathrm{mg} / \mathrm{L})$ and Coliform $(25.75-45.5 \mathrm{cfu} / \mathrm{ml})$ indicated non-significant variableness $(p>0.05)$ between Stations. Water depth, TDS, turbidity, TH, phosphate, nitrate and total coliform were significant contributors to the Anwai-river's water quality by Principal component analysis (PCA). The first principal component (PC1) exhibited $94.1 \%$ variance and a 0.1860 loading factor, while the second showed $5.9 \%$ variance and 0.0117 loading factor implying depth, flooding, excessive human activities and sewage disposal as important contaminants. Although the individual physiochemicalbased water qualities were below the WHO recommended drinking water values translated into poor water quality by the weighted arithmetic water quality index at the three Stations; 86.83, 75.02 and 81.27 in Station's 1, 2 and 3 respectively, correspondingly poor to very poor based on Water quality index. The water of Anwai-river is a serious health threat to humans and aquatic organisms and thus, it should not be utilized untreated.
\end{abstract}

Keywords: Anwai-river, Fecal-coliform, Water-parameters, Water-Quality Index

\section{INTRODUCTION}

Rivers play a critical role in establishing any nation's development goals and also on a global scale as they stimulate human and national wealth, civilization, and education levels while touching on all facets of the ecosystem and human endeavour (UN-waters, 2016; Smith et al., 2019). As a result, it is critical to ensure the suitability, use and acceptability of these scarce finite resources in terms of water quality standards and preservation of its core value uses are imperative. Surprisingly the usefulness and acceptability of the river's water quality have been severely defiled by anthropogenic impacts (Gupta et al., 2017). Thus, rivers' multiple uses have had effects on their characteristics. Globally, the river's water quality has deteriorated, negating one fundamental human rights: access to safe water. This issue remains one of the focal points of the UN-waters campaign, particularly in developing countries of the world (Ibrahim et al., 2015).

The global degradation of freshwater quality is a threat to the world's economy and health (Barbosa et al., 2016; Nwabor et al., 2016; Otene and Nnadi, 2019; Zakir et al., 2020; Bhutiani et al., 2021), particularly in developing nations like Nigeria where policies and laws are rarely implemented (lloba, 2021). The global degra- 
dation of freshwater bodies is disturbing, as poor or declining water quality results in the loss of essential goods and services (UN-waters, 2016) as well as a significant loss of needed foreign exchange (Oelsner et al., 2017).

Rainfall, erosion, discharged effluents from industrial and agricultural processes, and indiscriminate fecal deposition, xenobiotics, and a variety of other hazardous anthropogenic activities will impact water quality, particularly in surface freshwater bodies (Smith et al., 2019; Iloba, 2021). There are a few unaffected rivers in Nigeria regardless of status and area due to the expanding dimensions (diversity) of water demands and usage. As a result, despite the multiple antidotal waterquality regulatory laws and regulations, safeguarding and sustaining rivers within recommended standards has been a difficult challenge (Nwabor et al., 2016).

Historically, the evolution of the water quality concept around 160 years ago is an attempt to classify and evaluate the quality of the different aquatic ecosystems as a function of the various end-use of water concerning the water constituents, including the physical, chemical and biological components (Abbasi and Abbasi, 2012; Kachroud et al., 2019), instructive of water. Other indices evolved from and improved on this concept (Brown et al., 1970; Nemerow and Sumitomo, 1970; Deininger and Landwehr, 1971; Prati et al., 1971; Dinus, 1972; Bhargava, 1983; Tawari and Misha, 1985; Dinus, 1987). As a result, comprehending and interpreting these enormous factors for each water body (river) becomes complex and difficult. Water-quality experts were inspired to create various water-quality indices by employing water-quality indicator variables to properly define and interpret water quality (Abbasi and Abbasi, 2012). The development and application of these indices for assessing water quality assessment are considered highly sensitive and efficient (Gupta et al., 2017). These indices inform policymakers, the general public, and water managers about the state of freshwater ecosystems and provide information to water managers about the success or failure of the water quality management policies (Kangabam et al., 2017).

Aquatic ecosystems status assessments have received a lot of attention around the world, with various waterquality approaches. These indices are region-specific and have been used in water quality assessment, management and policy formulation in other countries reported in Amadi et al. (2010); Etim et al. (2013); Parastar et al. (2015); Kangabam et al. (2017), Gupta et al. (2017); Otene and Nnadi (2019) and Anyanwu and Ukaegbu (2019). One of such indices is the Water quality index (WQI) developed by Brown et al. (1972). The WQI employs mathematical equations to describe the general conditions of a water body by transforming water parameter data into a single numeral that genuinely defines the water quality (Abbasi and Abbasi, 2012; Kachroud et al., 2019).

In Nigeria, most water quality assessments focused primarily on the physical and chemical variables (Ezemonye et al., 2016; lloba et al., 2018; lloba, 2021). The approach by these researchers to river water quality study does not clearly define the river's water quality; rather than information on the concentration of the measured parameters in the sampled system. The Anwai river is a small stream that provides a primary water source for domestic and agricultural processes to the communities along its course. Previous studies on the Anwai river by Ezemonye et al. (2016) and Onyeche and Akankali (2013) relied solely on physiochemical data alone to describe the water body. The current study focused on determining the WQI approach in accessing the water-quality status of Anwai river in Delta State, Nigeria.

\section{MATERIALS AND METHODS}

\section{Study area}

The river Anwai, popularly called 'Mmili Anwai', is located in Delta State Capital Territory, Nigeria, between latitude $6^{\circ} 14^{\prime}$ and longitude $6^{\circ} 42^{\prime}$, with a terrain elevation of 37 meters (Fig. 1). The river originates in Otulu and empties into the river Niger at Asaba via the settlements of Isele-Azagba and Okpanam (lloba and Ada$\mathrm{mu}, 2020$ ). The river is a vital, well known, and muchneeded source of drinking, domestic water supply, agriculture and fisheries for the surrounding communities. It receives floodwater from the adjacent landscape, abattoir effluents and sacrifices-waste from point and non-point abattoirs. It is drained by a rainforest. Underground water supply and significant precipitation linked with the rainforest region ensure the river's flow. The current study concentrated on zones of human settlements with unrestricted access to the river to directly detect the water quality exposed to users; thus, no control Station was used. Three study Stations are depicted in Fig. 1 and are defined here to correspond to the river's numerous uses, as illustrated in Table 1.

\section{Settlement of Fulani cattle herders (Station 1)}

This is the source of the river in Delta State's OshimiliNorth Local Government Area (Fig. 1). This zone is referred to in this study as the livestock herders' Station due to the presence of the Fulani community settlements. Thus Station is used and drank from by the Fulani livestock. Additionally, the zone is home to the community's god shrine and worship centre. At this point, the river collects the bodies and blood of the sacrificed animals. The Station's waters are noticeably odorous due to the massive input of unpleasant points and non-point wastes from the goddess altar. 


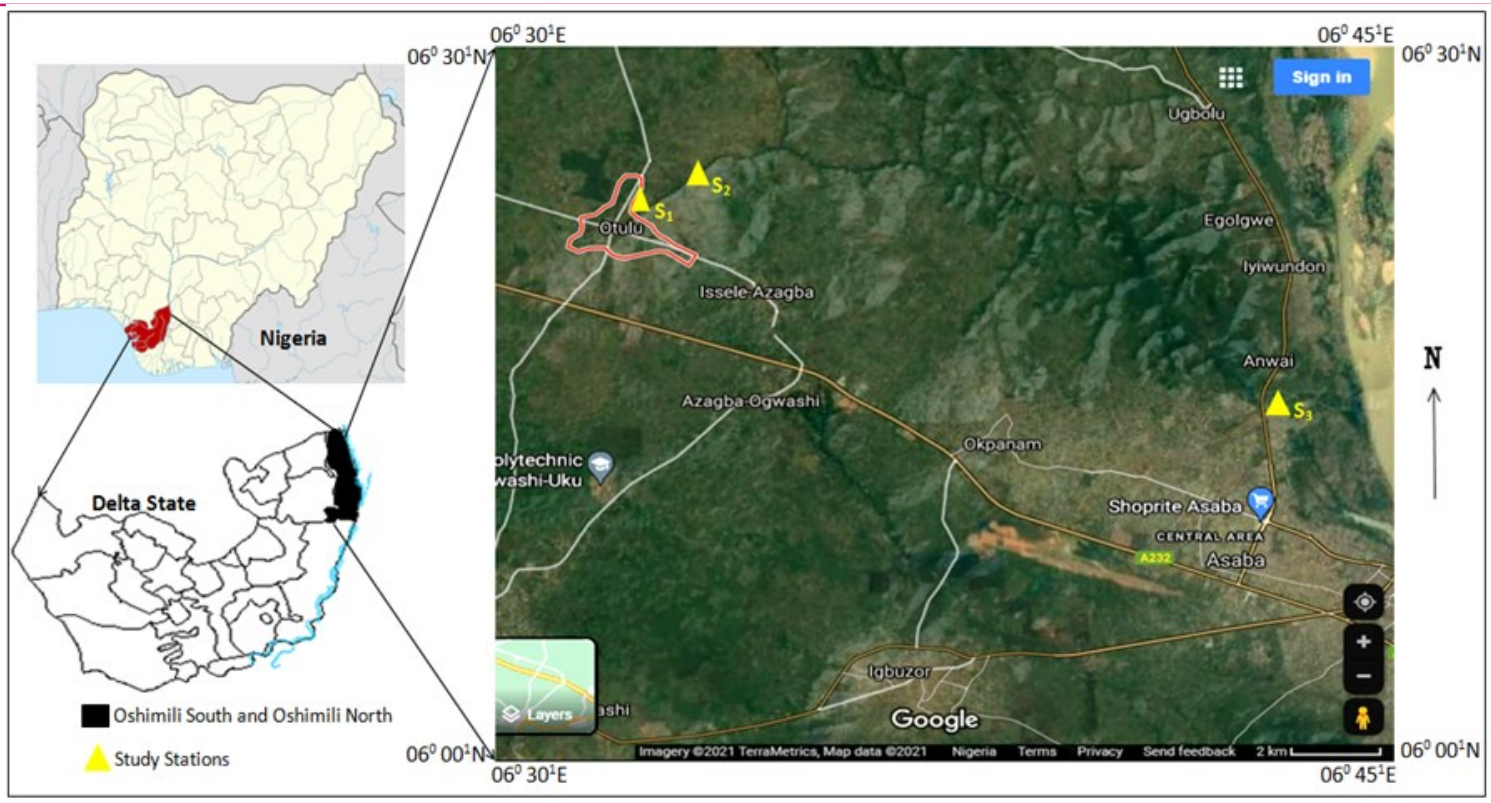

Fig. 1. Showing study area and the three sampled stations along Anwai-river in Delta State, Nigeria.

\section{Agricultural settlement (Station 2)}

The Isele- Asagba location which is also in Delta State's Oshimili-North Local Government Area, is the farmers' Station with spiritual significance to the IseleAzagba community. Due to its acclaim holiness, its barriers exclude women who are menstruating. Human activities are restricted to men farmers bathing and washing their clothes, sacrificing the River's goddess and washing the blood and bodies of slain animals into the River.

\section{Meat market in Anwai (Station 3)}

This Station in Delta State's Oshimili-South Local Government Area is home to Anwai-Asaba meat market (Fig. 1). This Station is bustling with human activities, car washing, clothing washing, bathing, and swimming. This zone is the principal beneficiary of the flood from the State Capital's Asaba metropolitan.

\section{Sampling}

Between March and May, 2019, a weekly water samples were taken in a properly cleaned 2-litre plastic water bottle from the three sampling Stations (Fulani cattle herders' community, Farm settlement and Anwai-meat Market) at a depth of $10-20 \mathrm{~cm}$ below the water surface. Water samples were collected and transported in an ice chest to the Department of Animal and Environmental Biology laboratory, Delta State University, Abraka, Delta, Nigeria, for analysis of water temperature, water depth, $\mathrm{pH}$, electrical conductivity, total dissolved solids, dissolved oxygen, alkalinity, turbidity, biological oxygen demand, phosphate, nitrate and total hardness. Each parameter was determined according to the American Public Health Association guidelines. The total coliform count was determined the same day, every sampling week throughout the sampling by multiple tube fermentation technique (APHA, 2017). The water quality index was interpreted using the scale created by Brown et al. (1972), as indicated in Table 2 (Boah et al., 2015).

\section{Data analysis}

To determine significant difference between the physicochemical parameters the result of the physicochemical parameters (water temperature, water depth, $\mathrm{pH}$, electrical conductivity (EC), total dissolved solids(TDS), dissolved oxygen(DO), alkalinity, turbidity, biological oxygen demand(BOD), phosphate, nitrate and total hardness $(\mathrm{TH})$ and total coliforms, one-way ANOVA and Turkey's pairwise test were used. Using the PAST statistical analysis tool software, Pearson linear correlation was performed to determine any association be-

Table 1. Stations and their geographic locations and activities associated with each station.

\begin{tabular}{lll}
\hline Station & Coordinates & Activities \\
\hline Station 1 (Otulu Station) & $6.286 \mathrm{~N}, 6.573 \mathrm{E}$ & $\begin{array}{l}\text { Fulani Cattle Herders settlement } \\
\text { Bathing, washing, Domestic use, a drinking water } \\
\text { source for cattle. }\end{array}$ \\
Station 2 (Isele- asagba Station) & $6.293 \mathrm{~N}, 6.582 \mathrm{E}$ & $\begin{array}{l}\text { Farm settlement with earthen ponds along the shore- } \\
\text { line(aquaculture activities), spiritual purpose and } \\
\text { swimming } \\
\text { Anwai-Meat Market, Abattoir, Mechanic workshops } \\
\text { Car wash services and drainage channel. }\end{array}$ \\
\hline
\end{tabular}


Iloba, K. I. et al. / J. Appl. \& Nat. Sci. 13(3), 913 - 922 (2021)

Table 2. Classification of water quality Index and status.

\begin{tabular}{ll}
\hline WQI INDEX & STATUS \\
\hline $0-25$ & EXCELLENT \\
$26-50$ & GOOD \\
$51-75$ & POOR \\
$76-100$ & VERY POOR \\
& UNSUITABLE FOR \\
ABOVE 100 & DRINKING \\
&
\end{tabular}

Source: Boah et al. (2015).

tween parameters (Hammer et al., 2001). Environmental metrics and Euclidean similarity index, such as the principal component analysis were used to separate the critical water variables affecting the river's water quality used to identify the Station's similarity. All parameters were log converted to unit inconsistency and make their unit less.

\section{Calculation of WQI}

The WQI was calculated using a weighted arithmetic water quality index established by Brown et al. (1972) for the National sanitation foundation (NSFW), sometimes referred to as NSFWQI. The following equation represents the weighted arithmetic water quality index (WQIA):

$$
W Q I_{A}=\sum_{i=1}^{n} w_{i} q_{i} / \sum_{i=1}^{n} w_{i}
$$

Where, $\mathrm{n}$ denotes the number of variables or parameters, wi is the relative weight of the ith parameter and, qi is the water quality rating of the ith parameter.

The unit weight (wi) of the various water quality parameters are inversely proportional to the recommended standards for the corresponding parameters.

$\mathrm{W}_{\mathrm{i}}=1 / \mathrm{S}_{\mathrm{i}}$, and $\mathrm{K}=$ constant given as; $\mathrm{K}=1 / \sum 1 / \mathrm{S}_{\mathrm{i}}$

$\mathrm{qi}=100[(\mathrm{Vi}-\mathrm{Vid}) /(\mathrm{Si}-\mathrm{Vid})]$

Where:

$\mathrm{Vi}$ is the observed value of the ith parameter, $\mathrm{Si}$ is the standard permissible value of the ith parameter and, Vid is the ideal value of the ith parameter in pure water. All the ideal values (Vid) are taken as zero for drinking water, except $\mathrm{pH}$ and dissolved oxygen (Tripathy and Sahu, 2005). For $\mathrm{pH}$, the ideal value is 7 and 14.6 for dissolved oxygen.

\section{RESULTS}

The results of the studied physicochemical and biological parameters studied in Anwai- river are summarized in Table 3. These parameters include water temperatures, $\mathrm{pH}$, water depth, DO, BOD, turbidity, TDS, alkalinity, EC, nitrates, phosphates and total coliform counts. Except for TDS, turbidity and total hardness, there was no statistically significant difference between the Stations $(p>0.05)($ Table 3$)$.

Table 4 shows the pairwise turkey analysis of the point of variableness between the Stations for the significant classical parameters $(p<0.05)$ are presented in Table 4. The paired Turkey's test indicated substantial TDS changes at Stations 2 and 3 as compared to with Station 1 , with values 0.00471 and 0.000193 , respectively. Turbidity varied by $3.35 \mathrm{E}-06(3,1)$ and $0.000189(3,2)$ at Stations 3 compared to Stations 1 and 2, whereas $\mathrm{TH}$ varied by $2.50 \mathrm{E}-11(3,1)$ and $5.19 \mathrm{E}-11(3,2)$ at Stations 3 compared to Stations 1 and 2. Table 5 displays the Euclidean similarity and distance index results.

The results of the WQI for Anwai River, derived by parameters $(\mathrm{pH}, \mathrm{EC}$, TDS, DO, Turbidity, BOD, Phosphate, Nitrate, TH and total coliforms) with more significant potential to affect the water quality for the WQI study are shown in Table 6 . These parameters and their mean values compared to standards recommended for drinking and for aquatic life are also shown in Table 6.

The mean values recorded for these parameters $(E C$, TDS, DO, turbidity, BOD, phosphate, nitrate and total coliforms) in Anwai river showed that apart from $\mathrm{pH}$, which fell within the range recommended by WHO, for drinking water and, all other water quality values (EC, TDS, DO, turbidity, BOD, phosphate , nitrate, TH) recorded throughout Anwai river at the three Stations were well below the recommended standards for drinking water and for aquatic life endorsed by Federal Environmental Protection Agency FEPA, (2003) and Standards Organisation of Nigeria SON, (2007).

The scale in Table 2 developed by Brown et al. (1972) used to interpret the water quality index as in Tables 6 showed that the WQI of the Anwai river at Stations 1, 2 and 3 , are $86.83,75.02$ and 81.27 , respectively.

\section{DISCUSSION}

The current study found that the $\mathrm{pH}$ (5.3-8.2), DO (2.0$2.8 \mathrm{mg} / \mathrm{L})$, BOD $(1.02-2.4 \mathrm{mg} / \mathrm{L})$, EC $(110-113 \mathrm{~S} / \mathrm{cm})$, turbidity (2.3-5.2 NTU), TDS (8.0-16.0 mg/L), TH (30-62 $\mathrm{mg} / \mathrm{L})$, phosphates $(0.13-0.28 \mathrm{mg} / \mathrm{L})$, and nitrates $(0.05-$ $0.27 \mathrm{mg} / \mathrm{L}$ ) values for the Anwai river met the minimum standards (WHO, 2017; FEPA, 2003 and SON, 2007). It demonstrates that the river is capable of supporting a diverse array of aquatic animals, since they meet the FEPA (2003), SON (2007), Nigerian Standard for Drinking Water Quality (2015) and WHO (2017), approved standards (Table 3). While the current study's DO content, a critical predictor of aquatic health, is below the reference level, it may indicate underlying stressful conditions in the river and is unlikely to confer high water quality on the river's aquatic biota.

The current study's low DO contents (2.23-2.24 mg/l) 


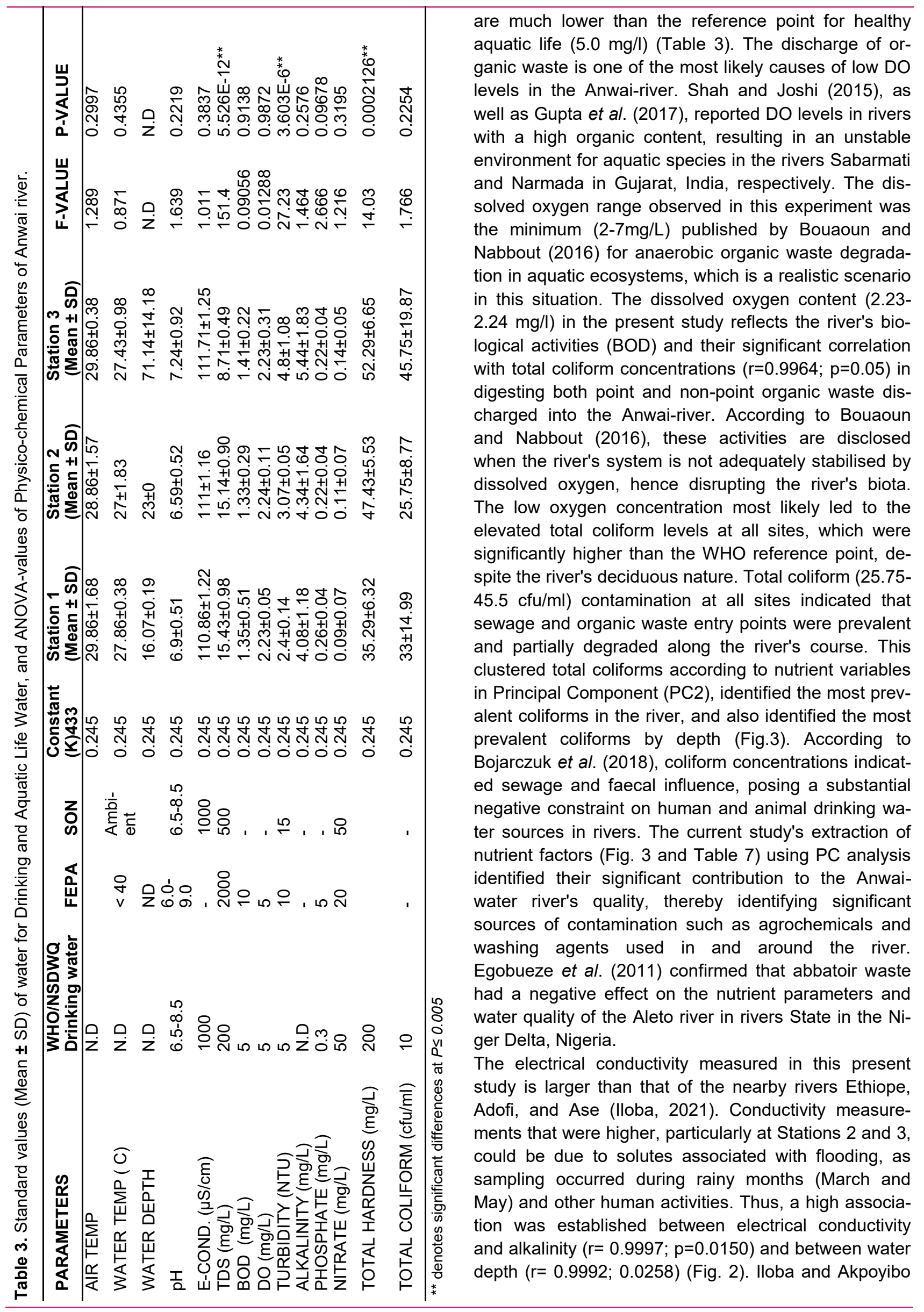


lloba, K. I. et al. / J. Appl. \& Nat. Sci. 13(3), 913 - 922 (2021)

Table 4. Comparison of Turkey's pairwise at the Stations.

\begin{tabular}{llll}
\hline Total Hardness & Station 1 & Station 2 & Station 3 \\
\hline Station 1 & & $0.00471^{*}$ & $0.000193^{*}$ \\
Station 2 & 5.194 & & 0.3285 \\
Station 3 & 7.272 & 2.078 & \\
\hline Turbidity & Station 1 & Station 2 & Station 3 \\
\hline Station 1 & & 0.1407 & $3.35 \mathrm{E}-06^{*}$ \\
Station 2 & 2.83 & & $0.000189^{*}$ \\
Station 3 & 10.11 & 7.285 & \\
\hline Total dissolved Solids & Station 1 & Station 2 & Station 3 \\
\hline Station 1 & & 0.7921 & $2.50 \mathrm{E}-11^{*}$ \\
Station 2 & 0.9258 & & $5.19 \mathrm{E}-11^{*}$ \\
Station 3 & 21.76 & 20.83 & \\
\hline
\end{tabular}

Table 5: Euclidean similarity and distance index values.

\begin{tabular}{llll}
\hline & $\begin{array}{l}\text { OTULU-HERDERS } \\
\text { SETTLEMENT }\end{array}$ & $\begin{array}{l}\text { AZAGBA-FARM } \\
\text { SETTLEMENT }\end{array}$ & $\begin{array}{l}\text { ASABA-MEAT } \\
\text { MARKET }\end{array}$ \\
\hline OTULU-HERDERS SETTLEMENT & 0 & 0.28462564 & $0.82643234^{*}$ \\
AZAGBA-FARM SETTLEMENT & 0.28462564 & 0 & $0.64943356^{*}$ \\
ASABA-MEAT MARKET & $0.82643234^{*}$ & 0.64943356 & 0 \\
\hline
\end{tabular}

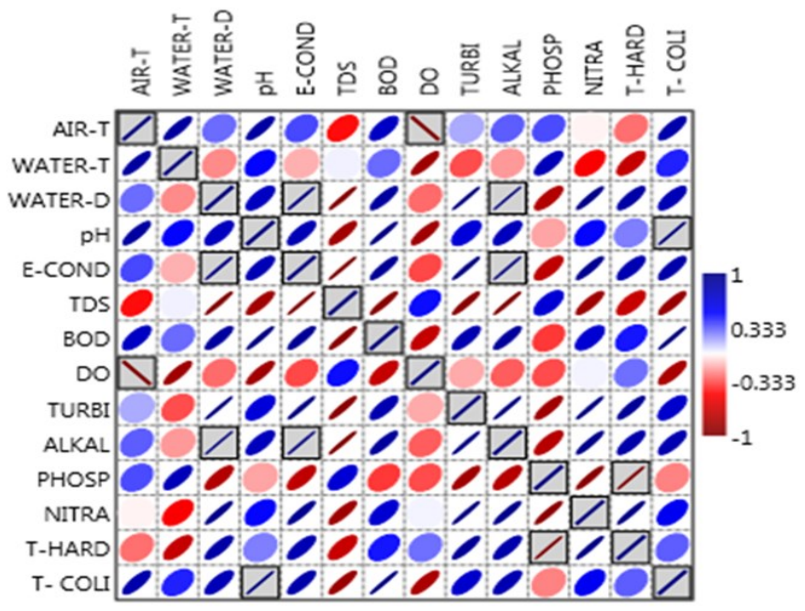

Fig. 2. Correlation matrix with $p<0.05$ boxed (Air temperature $=$ Air- $T$, Water temperature $=$ Water $-T$, Water depth $=$ Water-D, $p H=p H$, Electrical conductivity = E-COND, Total dissolved solids = TDS, Biochemical oxygen demand $=$ $B O D$, Dissolved oxygen $=D O$, Turbidity $=T U R B I$, Alkalinity $=$ ALKAL, Phosphate $=$ PHOSP, Nitrate $=$ NITRA, Total hardness $=T-H A R D$, Total coliforms $=T-C O L I)$.

(2019) have observed a comparable increase in conductivity in the aftermath of floods in the Warri river in Delta State, Nigeria. Additionally, the present study highlighted the effect of alkalinity on the electrical conductivity of the Anwai-river ( $r=0.94608)$, which is impacted by the bottom (water depth) ( $r=-0.9970$; $p=0.0497$ ) and creates particles necessary for microbial adhesion, survival, and proliferation (Fig. 3). These variables contributed to the river's total coliform count exceeding the WHO reference level, which is consistent with Bojarczuk et al. (2018)'s findings. In this study, the turbidity factor impacted the river's low clarity, reducing the amount of light reaching photosynthetic organisms and likely reducing autochthonous aeration, which may have enhanced the river's oxygen concentration. Thus, the comparatively DO value recorded at Station 3, which also had the highest turbidity and temperature, bolstered this claim ( $r=-1.0000 ; p=0.0000)$. Chapman (1999) defined impaired water bodies as those that have a BOD value of 4 or above and are unable to self-purify. The BOD values in this investigation were between 1.33 and $1.41 \mathrm{mg} / \mathrm{L}$, and hence can be regarded normal unpolluted water in the absence of any polluting-implicating characteristics. The antagonistic relationship between BOD and total coliforms may be explained by the river's deciduous nature, which allows for the recovery and restoration of the river's classical parameters such as BOD, DO, and TDS.

The temperatures observed in this study are consistent with those obtained by Ezemonye et al. (2016), Iloba and Adamu (2020) in the Anwai river, and lloba et al. (2018, 2019) in the Agbarha-Otor and Ethiope rivers, respectively. The observed very warm water temperatures could be explained by the interplay of effective heat transfer from the atmosphere to the river and the canopy cover surrounding the sampling points. Station 2 had somewhat colder mean temperatures than Stations 1 and 3 due to its dense plant cover. lloba and Egborge (2002), as well as Erhenhi (2019), have all documented and reported on the effect of vegetation cover on water temperature in the Ikpoba-river system, 


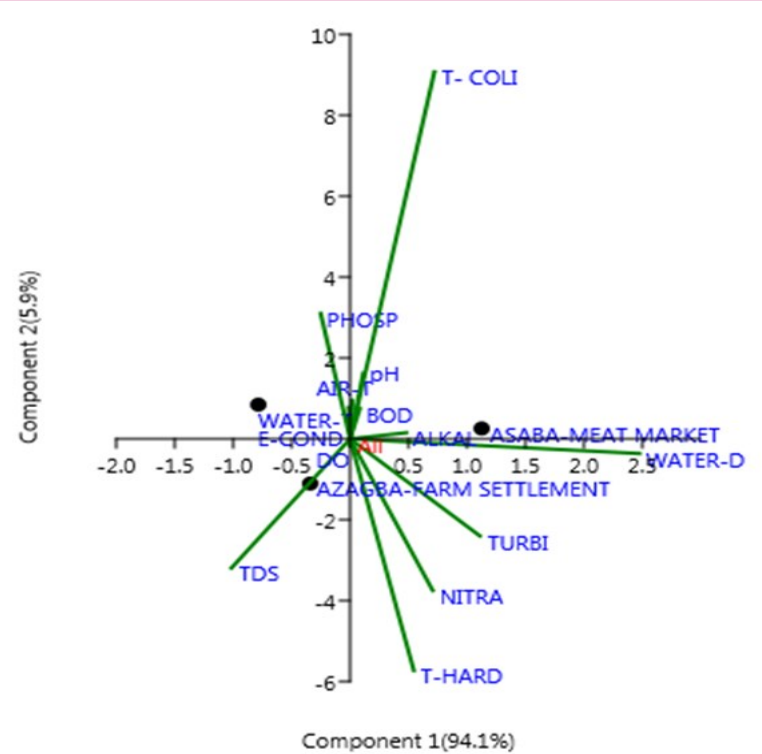

Fig. 3. Plot of the PCA of Anwai river based on the physiochemical parameters, total coliform at the various Stations.

Benin-City, Edo State, and Ofe river, Ondo State, Nigeria, respectively. The high temperature on this side of the tropics may also explain the study's DO values; water bodies such as the Anwai-river that reach temperatures above $20^{\circ} \mathrm{C}$ experience decreased oxygen dissolution or holding capacity, as noted by the Water Research Commission (WRC) for tropical water bodies. The negative connection between the Anwai river's water temperature and dissolved oxygen $(r=-0.86831)$ corroborates the effect of temperature on oxygen content. Shan and Joshi (2015) identified a similar phenomenon (association) on the Sabarmati River in Gujarat, India, during the summer. It has been stated that as the Sabarmati river's temperature increases, its DO's solubility decreases in the summer.

The PCA scalar vector analysis employed in this study indicated that total coliforms have a considerable effect on the river's water quality (Fig. 2). The isolation of the total coliform signature demonstrates the significant contribution of faecal and sewage contamination to the river's water quality, most likely as a result of indiscriminate dumping of human, livestock, and dead animal corpses and waste into the river, as Myers et al. (2017) also described aggregated PC1 and PC2 factor loadings indicated the presence of depth changes, associated sediment effect, nutritional factors, sewage and faecal loadings, and human activities such as dredging. Nonetheless, loadings of individual components varied greatly between locations. For instance, meat and agricultural processing plants produce organic substances in a linear pattern. The first primary component, organic load and floods, has a higher eigenvalue of 3692.2, accounting for $94.1 \%$ of the Anwai River's substantial fluctuation. Additionally, the ordination plot and Euclide-

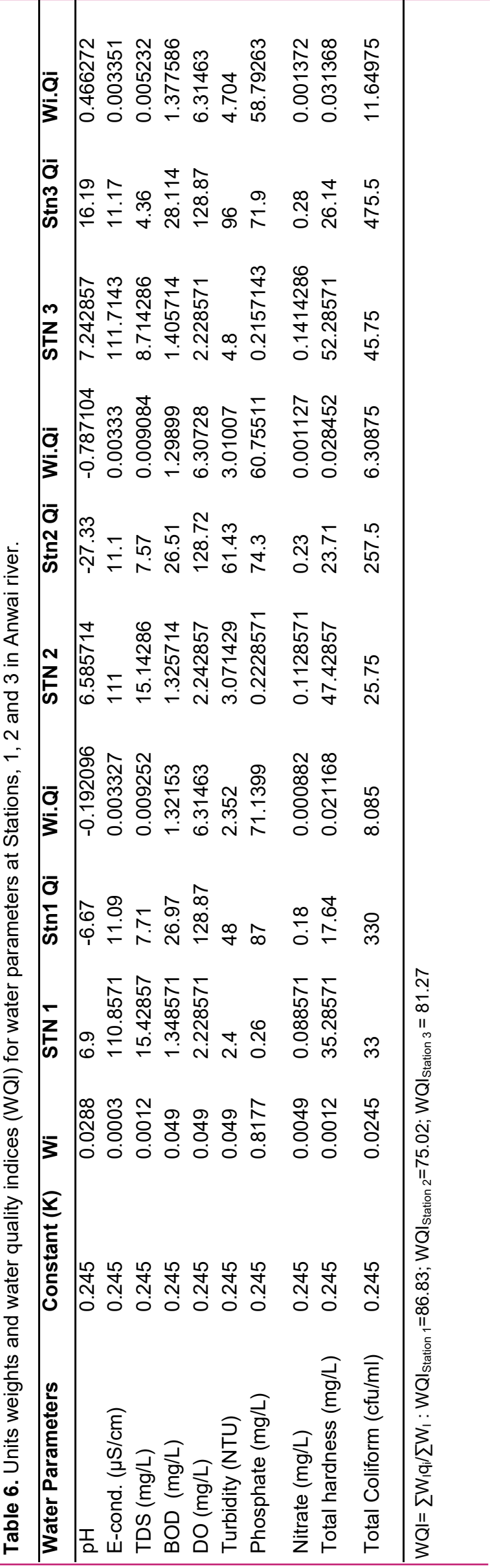


Table 7. Extracted parameters, loading factors, Eigen values and percentage of variation in Anwai river.

\begin{tabular}{lll}
\hline Parameters & Principal component 1 & Principal component 2 \\
\hline Eigenvalue & 0.185954 & 0.0116733 \\
\% variance & 94.093 & 5.9067 \\
Cum \% variance & 94.093 & 100.00 \\
Water depth & 0.78188 & - \\
TDS & -0.32067 & - \\
Turbidity & 0.35063 & - \\
Phosphate & - & 0.22341 \\
Nitrate & - & -0.29668 \\
Total hardness & - & -0.45324 \\
Total coliforms & - & 0.71824 \\
\hline
\end{tabular}

an index suggested that the Anwai-abattoir market Station was more distinct from the other two settlements (Fulani cattle herders' settlement and Farm settlement) (Fig. 1). This is especially true for the Anwai-abattoir market Station, which is located in the city's central business district and receives a significant amount of organic and sewage waste. At this moment in the changing environment, the channel expanded by dredging resisted the growing disruption created by human operations aquacultures along the Anwai river's beaches. Additionally, the eigenvalues (Table 7) indicated that water depth, TDS, turbidity, phosphate, nitrate, total coliforms, $\mathrm{pH}$, total hardness, and EC all had a role in the alterations that resulted in the Anwai river's poor water quality.

The Anwai river's WQI were assessed to be 86.83 , 75.02 , and 81.27 for Stations 1, 2, and 3. The WQI at three sampling points indicated severe pollution in the cattle header's settlement Station, severe pollution in the Asaba-anwai meat/abattoir Station, and serious pollution in the farm settlement Station. The exceedingly poor water quality at the livestock header's Station may be a result of excessive levels of cow faeces and indiscriminate human wastes washed into the river during rainfall. According to Myers et al. (2017), faecal contamination and indiscriminate human faeces have a significant impact on water quality. Subtle relaxations of traditional restrictions on the use of the Anwai-river may have led to the farmers' Stations' lower WQI. The Anwai river, according to this scale, is a source of drinking water with extremely poor water quality. This water status report unambiguously revealed that this body of water is being affected by anthropogenic activities in and around the river and natural processes.

\section{Conclusion}

The Anwai-water WQI indicates that this vital river in Asaba's capital metropolis has been under strong strain due to numerous operations in and around the river, resulting in a poor to extremely bad water-quality state.
With the isolation of pollutant water parameters such as DO and elevated total coliform counts, the river water has been classified as poor to very poor and unfit for human consumption, as well as unhealthy for aquatic biotas. As a result, the government should closely monitor all human-caused activities in order to avert future illness epidemics.

\section{Conflict of interest}

The authors declare that they have no conflict of interest.

\section{REFERENCES}

1. Abbasi, T. \& Abbasi, S.A. (2012). Water quality indices. The Boulevard, Langford Lane, Kidlington, Oxford, UK. 16

2. Amadi, A. N., Olasahinde, P. I., Okosun, E. A. \& Yisa, J. (2010). Assessment of the Water quality index of Otamiri and Oramiriukwa rivers. Physics International 1, (2), 116 123. https:// doi.org/10.3844/pisp.2010.166.123.

3. APHA/AWWA/WEF. (2017). Standard Methods for the Examination of Water and Wastewater. $23^{\text {rd }}$ Edition, American Public Health Association, American Water Works Association, Water Environment Federation, Denver.

4. Anyanwu, E. D. \& Ukaegbu, A. E. (2019). Index Approach to Water Quality Assessment of a South Eastern Nigerian river. International Journal of Fisheries and Aquatic Studies, 7(1), 153-159.

5. Barbosa, F. A. R., Callisto, M. \& Galdean, N. (2016). The diversity of benthic macroinvertebrates as an indicator of water and ecosystem health: A case study for Brazil. Aquatic Ecosystem Health and Management, 4(1), 51-59. https:doi.org./10.1080/146349801757569270.

6. Bhutiani, R., Ahamad, F. \& Ram, K. (2021). Quality assessment of groundwater at Laksar Block, Hardwar in Uttarkhand, India using Water Quality Index: A case study. Journal of Applied and Natural Science, 13(1), 197203. https:// doi.org /10. 31018 /jans.v13i1.2435.

7. Bhargava, D.S. (1983). Use of water quality index for river classification and zoning of Ganga river. Environ. Pollut. Ser. B Chem. Phys, 6, 51-67. https:// doi.org/10.1016/0143-148X(83)90029-0 
8. Boah, D. K., Twum, S. B. \& Pelig-Ba, K. B. (2015). Mathematical Computation of Water Quality Index of a Dam I Upper East Volta Region of Ghana. Environmental Sciences, 3(1), 11-16. http://dx.doi.org./10.12988/ es.2015.4116.

9. Bojarczuk, A., Jelonkiewicz, Ł., \& Lenart-Boroń, A. (2018). The effect of anthropogenic and natural factors on the prevalence of physicochemical parameters of water and bacterial water quality indicators along the river Białka, Southern Poland, Environmental Science and Pollution Research, 25,10102-10114. https://doi.org/10.1007/ s11356-018-1212-2.

10. Bouaoun, D. \& Nabbout, R. (2016). Study of physical and chemical parameters of Oustouan River, North Lebanon. Journal of Coastal Zone Management, 19,(3), 1-8. https://doi.org./10.4172/2473-3350.1000430

11. Brown, R. M., McClelland, N. I., Deininger, R. A. \& O'Connor, M. F. (1972). Water Quality Index-Crashing, the Psychological Barrier, Proc. 6th Annual Conference, Advances in Water Pollution Research, 787-794. http:// dx.doi.org/10.1016/b978-0-08-017005-3.50067-0.

12. Brown, R. M., McClelland, N.I., Deininger, R. A. \& Tozer, R.G. (1970). A Water Quality Index: Do We Dare? Water Sew. Works, 117, 339-343.

13. Chapman, D. (1999). Water Quality Assessment: A Guide to the Water source of Biota, Sediments and Water in Environmental Monitoring ( $2^{\text {nd }}$ Edition). Taylor and Francis, London and New York, 626.

14. Deininger, R. \& Landwehr, J. A. (1971).Water Quality Index for Public Water Supplies; Unpublished Report; School of Public Health, University of Michigan: Ann Arbor, MI, USA.

15. Dinus, S. (1972). Social accounting system for evaluating water resources. Water Resour. Res., 8, 1159-1177.

16. Dinus, S.H. (1987). Design of an index of water quality. J. Am. Water Resour. Assoc., 23, 833-843. https:// doi.org/10.1111/j.1752-1688.1987.tb02959x

17. Egobueze, E. E., Iwegbue, C. M. A. \& Arimoro, F.O. (2011). Effects of Abattoir wastes on the water quality of Aleto river in the Niger Delta, Nigeria. Tropical freshwater Biology, 20, 91-102. https:// doi.org/10.4314/tfb.v20i17

18. Erhenhi, A. H. (2019). Vegetation along river Bank (Riparian) In Ondo State, Nigeria. Int. J. of Life Sciences, 7(4), 625-630.

19. Etim, E. E., Odoh, R., Itodo, A. U., Umoh, S. D. \& Lawal, U. (2013). Water Quality Index for the Assessment of water quality from different Sources in Niger-Delta Region of Nigeria. Frontiers of Science, 3(3), 89-95.20. https:// doi.org/10.5923/j.fs.20130303.02.

20. Ezemonye, M. N., Osaituma, S. I. \& Emeribe, C.N. (2016). Impact of Abbatoir waste on the physicochemical quality of Anwai River, Asaba Delta State Nigeria. European Scientific Journal, 12(20). https://doi.org/10.19044/ esj.2016.v12n20p288.

21. Federal Environmental Protection Agency (FEPA) (2003). Guidelines and Standards for Environmental Pollution Control in Nigeria. 238 pp.

22. Gupta, B. G., Biswas, J. K. \& Agrawal, K. M. (2017). Physico-chemical parameters, water quality index and statistical analysis of surface water contamination by bleaching and dyeing effluents at Kalikapur, West Bengal, India. J. Env. Sci. Pollut. Res., 3(2), 177-180.
23. Hammer, H. D. A \& Ryan, P. D. (2001). Paleontological statistics software package for education and data analysis. Palaeontologia Electronica, 4(1), 1-9.

24. Ibrahim, A. E. M., Osman, B. O., \& Mohamed-Ali, M. H. (2015). Assessment of Physicochemical parameters of surface water sources in Kusti Town - Sudan. European Journal of Pharmaceutical and Medical Research, 2(4), 44 $-58$.

25. Iloba, K. I., Akawo, O. N. \& Nwaefiene, F. (2018). Diversity and community structure of macroinvertebrates in Arthropogenically stressed water body in Delta state, Nigeria. IJABR. 9(1), 93 - 106

26. Iloba, K. I. \& Akpoyibo, C. E. (2019a). Specific Physicochemical Parameters Influence on the Plankton Structure in Agbarho-Ogbe-ljoh Stretch of Warri river. Nigeria. Journal of Biodiversity and Environmental Sciences, 15(5),92105.

27. Iloba, K. I. \& Adamu, K. M. (2020). Ecological Responses of Macroinvertebrates to Human-Impacts of a Rural-Urban Flowing river in Delta State in Delta State, Nigeria. Journal of Biodiversity and Environmental Sciences, 16(4), 10-18.

28. Iloba, K. I. \& Egborge, M. B. (2002). Changes in the rotifer community of the Ikpoba Dam, Benin-City. Tropical Freshwater Biology, 11, $37 \quad-46 . \quad$ https:doi.org/10.4314/ tfb.v11i1.20867

29. Iloba, K. I., Akawo, N. \& Anani, C. (2019). Sand Dredging Impact on Macrobenthic Invertebrates of a hallowed river in Delta State of Nigeria. Science World Journal, 14(1), 171-176.

30. Iloba, K. I. (2021). Algal homogeneity in water and sediment of mid-Ethiope river, Nigeria: a response to severe ecological disturbances. Global Nest Journal, 23, (1), 4756. https://doi.org/10.30955/gnj.003214

31. Kangabam, R. D., Bhoominathan, S. D., Kanagaraj, S. \& Govindaraju, M. (2017). Developing a water quality index for Loktak Lake in India. Appl Water Sci, 7, 2907-2918 DOI 10.1007/s13201-017-0579-4

32. Kachroud, M., Trolard, F., Kefi, M. Jebari, S. \& Bourrié, G. (2019). Water Quality Indices: Challenges and Application Limits in the Literature. Water, 11, 361. doi:10.3390/ w11020361.

33. Myers, L., Fiske, M. \& Layhee, M. (2017). Elevated Stream Pathogenic Indicator Bacteria Concentrations in Livestock Grazing Areas across a Single National Forest. Natural Resources, 8, 657-670. https://doi.org/10.4236/ nr.2017.81004.

34. Nemerow, N. L. \& Sumitomo, H. (1970). Benefits of Water Quality Enhancement (Part A: Pollution Index for Benefits Analysis); Water pollution control research series N.16110 DAJ 12/70, Environmental Protection Agency, Water Quality Office: New York, NY, USA.

35. Nigerian Standard for Drinking Water Quality (2007). Nigerian Standard for Drinking Water Quality (NSDWQ). Nigerian Industrial Standard, NIS: 554, pp. 13-14.

36. Nwabor, O. Forstinus, N., Emmanuel, I., Martins, P. E. \& Ani Ogonna Christiana (2016). Water and Waterborne Diseases: A Review. International Journal Of Tropical Disease \& Health, 12(4), 1-14. Article no.IJTDH.21895 ISSN: 2278-1005, NLM ID: 101632866.

37. Oelsner, G.P., Sprague, L.A., Murphy, J.C., Zuellig, R.E., Johnson, H.M., Ryberg, K.R., Falcone, J.A., Stets, E.G., Vec-chia, A.V., Riskin, M.L., De Cicco, L.A., Mills, T.J. \& 
Farmer, W.H. (2017). Water-quality trends in the Nation's rivers and streams, 1972-2012-Data preparation, statistical methods, and trend results: U.S. Geological Survey Scientific Investigations Report 2017-5006, 136 p., https:// doi.org/10.3133/sir20175006

38. Onyeche, L. A. \& Akankali, J. A. (2013). Determination of some environmental parameters of Anwai stream, Niger Delta, Nigeria. Research Journal of Agricultural and Environmental Management, 2(6), 142-149.

39. Otene, B. B. \& Nnadi, P.C. (2019). Water Quality Index and status of Minichinda Stream, Port-Harcourt, Nigeria. Ilard International Journal of Geography and Environmental Management, 5(5), 2505-8221.

40. Parastar, S., Jalilzadeh, A., Poureshg, Y., Hashemi, M., Rezaee, A. \& Hossini, H. (2015). Assessment of national sanitation foundation water quality index and other quality characterization of Mamloo dam and supporting streams. Int J Env Health Eng, 4,44.

41. Prati, L., Pavanello, R. \& Pesarin, F. (1971). Assessment of surface water quality by a single index of pollution. Water Res., 5, 741-751. https://doi.org/10.1016/0043-1354 (71)90097-2

42. Shah, K. A. \& Joshi, G. S. (2015). Evaluation of water quality index for River Sabarmati, Gujarat, India. Applied Water Science. Doi.org/10.1007/s13201-015-0318-7. https://doi.org/10.1007/s13201-015-0318-7

43. Smith, W.S., Silva, F. L. \& Biagioni, R. C. (2019). River dredging: when the public power ignores the causes, biodiversity and science. Ambiente \& Sociedade $n$ São Paulo, 22, 22. e00571. https://doi.org/10.1590/1809-4422asoc 007r1vu19L1AO

44. Standards Organisation of Nigeria (2007). Nigerian standard for drinking water quality. Nigerian Industrial Standard (NIS 554). Standards Organisation of Nigeria (SON), Abuja, Nigeria. pp. $14-17$.

45. Tawari, T. \& Mishra, M. (1985). A preliminary assignment of water quality index of major Indian rivers. Indian J. Environ. Prot, 1, 276-279.

46. Tripathy, J. K. \& Sahu, K. C. (2005). Seasonal hydrochemistry of groundwater in the barrier-spit system of Chilika lagoon. Journal of Environmental Hydrology, 12 (7), 1-9.

47. UN-waters. (2016). Towards a Worldwide Assessment of Freshwater Quality: A UN-water Analytical Brief. pp. 40.

48. World Health Organization (2017). Guidelines for drinking water quality. World Health Organization (WHO). First Addendum to the $4^{\text {th }}$ edition. ISBN 9789241548151. Pp. 564.

49. Zakir, H. M., Sharmin, S., Akter, A. \& Rahman, M. S. (2020). Assessment of health risk of heavy metals and water quality indices for irrigation and drinking suitability of waters: a case study of Jamalpur Sadar area. Bangladesh Environmental Advances, 2, 100005. doi.org/10.1016/ j.envadv.2020.100005. 